\title{
A világjárvány hatása az emberkereskedelemre az első két év tapasztalatai alapján ${ }^{1}$
}

\author{
The Impact of the Pandemic in Human Trafficking \\ Based on the First Two Years
}

\author{
Windt Szandra \\ Dr. PhD, tudományos fömunkatárs, \\ Országos Kriminológiai Intézet \\ windt@okri.hu
}

\begin{abstract}
Absztrakt
2020 kiemelkedő év volt a hazai emberkereskedelem elleni fellépésben: fontos jogszabályi változások mellett hatályba lépett az emberkereskedelem elleni stratégia. Ugyanakkor ez volt az az év, amikor meg kellett tanulnunk, hogy egy parányi kórokozó hogyan változtatja meg egyik napról a másikra az életünket. 2020 márciusától jelen sorok írásáig a koronavírus-világjárvány negyedik hullámát éljük Magyarországon: a társadalmi, gazdasági hatásainak vizsgálata emiatt különösen nehéz. Korántsem látjuk a járvány végét, az egyes hullámoknak más és más hatásai voltak, ezek feltárása, megismerése hosszabb időt igényel. Cél: Ebben a tanulmányban a 2021 őszén rendelkezésre álló ismereteket öszszegezzük, kifejezetten az emberkereskedelemmel összefüggésben, kiemelve, hogy ezek részben hipotézisek, amelyek igazolása vagy cáfolata a következő évek feladata lesz. 2021 őszére az emberkereskedelem tényállása alapján indult ügyek számának emelkedése számottevő, felmerül a kérdés azonban, hogy ennek okai miben keresendők. Van-e, lehet-e kapcsolat a világjárvánnyal, illetve mi a tapasztalat a gyakorló szakemberek, áldozatok szemszögéből?
\end{abstract}

Módszertan: A tanulmány elkészítéséhez a rendelkezésre álló nemzetközi és hazai szakirodalom feldolgozása mellett mélyinterjúk készültek emberkereskedelem áldozataival.

Megállapítások: A 2020 óta tapasztalható ügyszám emelkedés a 2018 óta ezen a területen, ám különböző szerveknél (ügyészség, rendőrség, gyermekvédelem) közel egy időben elinduló folyamatok eredménye, és egyelőre a számokban a pandémia hatása nem mutatkozik meg, bár a módszerek változása már tetten érhető.

1 A tanulmány a Bolyai János Kutatási Ösztöndíj támogatásával készült. 
Érték: A járvány emberkereskedelemre gyakorolt hatásainak első összegzése a nemzetközi szervezetek anyagaiban már olvashatók, de országspecifikus, a hazai megközelítést tartalmazó még nem készült. A Bolyai János Kutatási Ösztöndíjnak köszönhetően további interjúk, fókuszcsoportos beszélgetések során folytatódik a világjárvány emberkereskedelemre tett hatásának vizsgálata.

Kulcsszavak: emberkereskedelem, koronavírus-járvány, Magyarország, áldozat

\begin{abstract}
2020 was a landmark year in the fight against trafficking in human beings in Hungary: the anti-trafficking strategy came into force, along with important legislative changes. It was also the year when we had to learn how a tiny pathogen can change our lives overnight. Between March 2020 and the time of writing this article, we are experiencing the fourth wave of the coronavirus pandemic in Hungary, making it particularly difficult to assess its social and economic impact. We are far from seeing the end of the epidemic, each wave has had different effects, and it will take longer to explore and understand them.
\end{abstract}

Aim: This paper summarises the knowledge available in autumn 2021, specifically in the context of trafficking in human beings, stressing that these are partly hypotheses which will have to be confirmed or refuted in the years to come. By autumn 2021, there has been a significant increase in the number of cases of trafficking in human beings, but the question arises about the reasons for this. Is there, or could there be, a link with the pandemic, and what is the experience of practitioners and victims?

Methodology: The study was based on a review of the available international and national literature and in-depth interviews with victims of trafficking.

Findings: The increase in the number of cases since 2020 is the result of a process that has been underway in this area since 2018, but at different bodies (prosecution, police, child protection) at almost the same time, and the numbers do not yet reflect the impact of the pandemic. However, changes in methods are noticeable.

Value: A first synthesis of the consequences of the epidemic on trafficking in human beings is already available in the materials of international bodies, but a country specific approach, including a domestic one, has not yet been developed. Thanks to the Bolyai János Research Fellowship, further interviews and focus group discussions will be conducted to explore the impact of the pandemic on human trafficking.

Keywords: trafficking in human beings, pandemic, Hungary, victim 


\section{Bevezetés}

A hazai emberkereskedelem tekintetében 2013 jelentős év volt: a Varsói Egyezmény, a 2011/36/Eu irányelv a hazai jogrendszer részévé vált, az új Btk. és a 2013-2016 közötti négy évre szóló nemzeti stratégia hatályba lépett (Windt, 2014). 2020-ban hasonlóan fontos, az emberkereskedelem elleni fellépés miatt jelentős jogszabályok születtek, sajnálatos azonban, hogy az emberkereskedelem jelensége ellen tett lépéseket, és a már látható eredményeket elhomályosította egy világjárvány, sőt újabb kihívások elé állított mindannyiunkat.

A Nemzetközi Munkaügyi Szervezet (International Labour Organisation; ILO) szerint a 2020-as pandémia „térdre kényszeritette a munkaerőpiacot” (International Labour Organization, 2020). A közegészségügyi kockázatokon túl a vírus megfékezésére hozott védelmi intézkedések olyan töréseket okoznak a gazdaság és a társadalom életében, amelyek milliók jóllétét sodorják veszélybe. Az ILO 2020. márciustól tekinti át a járványnak a munka világára gyakorolt hatását: a gazdasági, társadalmi folyamatokat, amelyek nyilvánvalóan nyomot hagynak az elkövetkezendő időszak emberkereskedelemére is majd, de hatásuk feltárása még időt vesz igénybe (Holka, 2021).

Az emberkereskedelem során az emberi méltóságot súlyosan sértő cselekmények valósulnak meg. A sértettek ezen büncselekmények következtében rendkívül rossz fizikai és mentális állapotba kerülnek, amely az egyéni nehézségeken, problémákon túl össztársadalmi szinten is (pénzben kifejezhető) károkat okoz nemcsak nekik, hanem mindannyiunknak. Az Európai Bizottság számításokat készíttetett az emberkereskedelem áldozatainak költségeivel kapcsolatban: a 2020-ban megjelent publikációban a 2016-os áldozati adatokkal számoltak, uniós szinten, mégis érdemes átgondolni (European Comission, 2020). E szerint egy áldozat kb. 112 millió forintba kerül; a gyerekkorú és női áldozatok még többe. A megelőzéstől, a büntetőeljáráson keresztül, a sértett kieső munkájának értékét, az ő fizikai és mentális egészségének helyreállításának költségeit mind beleszámítják (European Comission, 2020). A bünelkövető (hasznot, előnyt) pénzt szerez, de ennek árát az áldozat mellett a társadalmunk is megfizeti (Windt, 2021a).

\section{A pandémiáról röviden}

A COVID-19-világjárvány a SARS-CoV-2 vírus által a COVID-19 elnevezésü betegséget okozó pandémia, koronavírus-járvány. A pandémia két éve tart világszerte, 2021 őszén a negyedik hullámban vagyunk. Az előző három hullám 
elsődleges tapasztalatai alapján elmondható, hogy mindegyik egy kicsit más volt, korántsem egységes kép rajzolódik ki. 2020 februárjáig csak a riasztó nemzetközi híreket hallottuk a vírusról, annak terjedéséröl, a veszélyeztetett csoportokról és a teendőkről napról-napra bővült az ismeretünk.

2020 elején el sem tudtuk képzelni, hogy a kínai események közép-európai életünket is befolyásolni fogják. Ez azonban a mindennapjaink része lett: 2020-ban az országos kijárási korlátozások három hónapra az otthonukba kényszerítették a legtöbb magyar állampolgárt, a bezárt óvodák és iskolák miatt a szülőknek kellett - a munkájuk mellett - a gyermekeik napközbeni ellátását is biztosítaniuk. Nem beszélve az általános bizonytalanságról, hiszen 2020 tavaszán még alig volt információnk a tekintetben, hogy mivel állunk szemben, és az ellen hogyan lehet hatékonyan fellépni. Sokan elveszítették a munkájukat, de szerencsére az első hullám kevés áldozatot követelt hazánkban.

A járvány megjelenését követően szinte azonnal felmerült egy rendkívül fontos és nehéz kérdés: mekkora egészségkockázatot vállaljon a társadalom annak érdekében, hogy müködőképessége megmaradjon. Markánsan kirajzolódott, hogy egy világjárvány a mai globalizált világunkban térdre kényszerítheti a gazdasági, pénzügyi, egészségügyi, szociális, kulturális, közlekedési, turisztikai, oktatási és sok más egyéb szférát (URL1).

A vírus terjedésének megfékezésére szinte azonnal két lépés meghatározására került sor: a maszk viselése mellett, az emberek közötti érintkezések számának csökkentése volt a legfontosabb. Emiatt a társadalmi távolságtartás kifejezést 2020-ban tanultuk meg, ugyanakkor az első hullámban a vírus terjedését sikeresen csökkentve a társadalmi kapcsolattartás, a személyes kontaktus elmaradása komoly mentális problémákhoz vezetett. A TÁRKI kutatása szerint az általuk megkérdezettek 16\%-a tapasztalt lelki problémákat, az életkor emelkedésével és a kisebbtől a nagyobb létszámú településtípusok felé haladva egyre nagyobb arányban: az idősebb, a járvány által leginkább veszélyeztetett korcsoportba tartozó személyek és a fővárosiak között a mentális panaszok előfordulása gyakoribb (Tóth \& Hudácskó, 2020).

Osváth Péter szerint a vírusfertőzés akut következményei mellett egyre több adat bizonyítja a teljes népességre kifejtett negatív hatásait: a pszichológiai distressz, a depressziós és szorongásos tünetek, valamint az addiktív viselkedésformák gyakoriságának növekedését (Osváth, 2021). Sőt, hozzáteszi: a „pandémia következtében kialakuló mentális gondok és a suicid viselkedés egyre fontosabb népegészségügyi problémává válnak" (Osváth, 2021).

Szinte senki nem függetlenítheti magát a világjárvány okozta korábbi elképzeléseink megingásától az elmúlt két évben. Az egészségügyi kockázatok, továbbá az emberi szervezetre gyakorolt hatása mellett, a COVID-19-járvány 
a gazdaságra is rendkívüli kihatással van. ,Alapvetöen kijelenthetjük, hogy az egész világot megrázó járványügyi kihívások két kiemelt területet érintenek: elsösorban az egészséget, az emberi élet védelmét, másrészt a gazdaság müködését." (Túróczi et al., 2020).

A 2019 ősze óta tartó világjárvány rendkívül gyorsan rámutatott arra, hogy globalizált világunkban a fizikai távolság gyakorlatilag nem jelent biztonságot a vírus terjedését illetően, hiszen azt a közvetlen repülőjáratokkal, utazások során egyszerủen át lehetett hidalni. Valamint az is egyértelmüvé vált, hogy a pandémia okozta egészségügyi korlátozások mellett a gazdasági krízis is mindenkit érint és érinteni is fog.

Az első hullám során „Magyarországon is közéleti vita alakult ki arról, hogy mi okoz nagyobb kárt: maga a járvány vagy a vírus terjedését akadályozó korlátozások. Ennek az ellentétnek ráadásul generációs vetülete is van. A fiatalokra nézve a járvány egészségügyi kockázata kisebb, míg a gazdasági, pénzügyi hatása lényegesen nagyobb. A nyugdíjas korosztály ezzel szemben kevésbé érzi meg a gazdasági hatásokat, az egészségügyi kockázat esetükben ugyanakkor rendkivïl magas. Erröl a kérdésröl nagyon eltéröen vélekednek a fiatalok és az idösebbek. Mig a 60 év felettiek 55-27 arányban az emberi életek elveszitéséért aggódtak jobban, addig a 18-29 évesek 55-33 arányban a gazdasági következményekért." (Hunyadi \& Molnár, 2020).

A korábbi járványok tapasztalatai alapján azok hatása hosszú távon a társadalmi egyenlőtlenségek csökkenésével jár együtt, ugyanakkor ez a negyedik hullámban már kijelenthető: a koronavírus-járványra valószínüleg nem lesz jellemző. A 2020 tavaszi első hullámot követően az volt a tapasztalat, hogy „súlyosabb csapást mért a járvány nyomán kialakult gazdasági válság az alacsonyabb bevétellel rendelkezö, kiszolgáltatottabb rétegekre. Munkahelyük nagyobb valószinüséggel szünt meg hirtelen a korlátozások következtében, egyhavi bevételük hirtelen kiesése pedig jóval nagyobb relativ hiányt jelent számukra." (Hunyadi \& Molnár, 2020).

\section{Az emberkereskedelem jelensége (2019-2021)}

Az emberkereskedelemmel kapcsolatban 2018 óta történtek fontos, egymástól független események, amelyek összeadódva mégis eredményeket mutattak ezen a területen. Emiatt lehetséges az, hogy szinte minden szervezet a saját sikerének könyveli el a már érzékelhető kisebb-nagyobb eredményeket. Már a nemzetközi megfigyelők is megfogalmazzák, hogy ugyan van még mit tenni, de elismerésüket fejezik ki a már megtett előremutató tevékenységeket illetően. 
Kiemelendő, hogy 2018-ban a gyermekvédelemben dolgozók számára elkészült egy tananyag „Gyermekprostitúció és gyermekkereskedelem” címmel (Hatvani, Sebhelyi \& Vaskuti, 2018). Ez minden gyerekvédelemben dolgozó számára kötelező, a képzési rendszer része lett. Ez a gyermekvédelem területén hozzájárult egy szemléletváltáshoz, amely különösen akkor érzékelhető, ha az ezen a területen készült korábbi ombudsmani jelentéshez ${ }^{2}$ hasonlítjuk. Emellett fontos lépés volt annak megfogalmazása is a gyermekvédelemben dolgozók számára, hogy ha valaki 18 éves kor alattit kihasznál, vagy valaki ezt a tevékenységet bármilyen módon segíti, abban az esetben a gyermekkorú részéről semmiféle önkéntesség nincs, azaz, ahogy Hatvani Erzsébet fogalmazott a gyermekprostitúcióról szóló megbeszélésünkön: ,aki még nincs 18 éves, az tabu”. Tabu annak is, aki a gyermeket ellenszolgáltatás vagy annak ígérése fejében kihasználja, és annak is, aki ebben közremüködik (Windt, 2021b).

A jogalkalmazói oldalról az elmúlt években a szemléletváltozáshoz több dolog is hozzájárult, amelyek 2021 végére már számokban kimutatható eredményekben mutatkoznak.

Az Országos Rendőr-fôkapitányságon utasításokkal, belső normákkal alakítják az egységes gyakorlatot, az ügyészség szervezetén belül állásfoglalások és iránymutatások tartalmazzák a követendő elveket, gyakorlatot. Az említett ügyészségi iránymutatás(ok) azonban ebből a szempontból némileg túlmutat(nak) a szervezet keretein. Ez az ügyészség büntetőeljárásban betöltött szerepének köszönhető. Az egyik különösen fontos lépés az volt, hogy 2018 októberében a Legfőbb Ügyészség kiadta a KSB 3771/2018/5-I. - NF. 3889/2014/11-es számú iránymutatását, amelyben az emberkereskedelem esetében a kizsákmányolás és a kiszolgáltatott helyzet értelmezése, a kerítés büncselekményétől való elhatárolása olvasható. Az iránymutatást követően a folyamatban lévő ügyeket felül kellett vizsgálni minden ügyészségi szervezeti egységnek, és annak szellemében kellett újragondolni az egyes bűncselekmények minősítését.

Ezt követően 2019 májusában egy kiegészítő iránymutatás (KSB 3771/2018/45II. - NF. 3889/2014/17-II.) készült az emberkereskedelem büntette sértettjeinek azonosításával, valamint annak kiemelésével kapcsolatban, hogy ezen sértettek különleges bánásmódot igénylő személyként kezelése nagy valószínüséggel a legtöbb esetben fennáll.

2 OBH 550/1998. Az állampolgári jogok országgyűlési biztosa általános helyettesének jelentése, Az otthont nyújtó gyermekintézményekben élő gondozottak alkotmányos jogainak érvényesülése. Majd 2011-ben az országgyülési biztos AJB-1472/2011. számon, a gyermekek védelemhez és gondoskodáshoz való jogának védelme érdekében hivatalból vizsgálatot folytatott annak feltárására, hogy jelen van-e hazánkban a gyermekprostitúció jelensége, és a gyermekek védelmére hivatott szervek milyen intézkedéseket tesznek akkor, ha ezzel a jelenséggel találkoznak. Ezt követte az AJB-1485/2018. számú jelentés 2018-ban. 
Ettől függetlenül 2019 őszén az Országos Rendőr-főkapitányság Bünügyi Főigazgatóságán egy emberkereskedelem szakvonalvezetőt jelöltek ki, akinek egyik feladata a megyei (fővárosi) rendőr-főkapitányságokon szintén kijelölt emberkereskedelem szakvonalvezetők munkájának irányítása, folyamatos képzésük biztosítása.

2019 őszétől 2021 őszéig a Belügyminisztérium összesen hét szemléletformáló tréninget szervezett a rendőrök, ügyészek, bírák részvételével, amelyek hatása szintén számottevő. (Az első szemléletformáló tréningről olvasható egy összegzés: Huszár \& Windt, 2020.)

2020 elején a Kúria elnöke felállította „Az emberkereskedelem értelmezésével kapcsolatos birói gyakorlat" címü joggyakorlat-elemző csoportot (Somogyi, 2020), amelynek jelentése 2022 tavaszán várható, és amely segítséget jelent majd a bíráknak a fennálló értelmezési kérdésekben.

2019-tôl a jogalkotó is fontos jogszabályokat alkotott az emberkereskedelemmel kapcsolatban: 2020 februárjában hatályba lépett az 1046/2020. (II. 18.) Korm. határozat az emberkereskedelem elleni küzdelemről szóló 2020-2023 közötti nemzeti stratégiáról, valamint annak végrehajtását szolgáló, a 2020 2021 közötti időszakban végrehajtandó intézkedési tervről, amelynek első stratégiai célkitüzése: kiemelt figyelem fordítása az emberkereskedelem 18 év alatti áldozataira.

A 2020. évi V. törvény Az emberkereskedelem áldozatainak kizsákmányolása elleni fellépés érdekében szükséges egyes törvények módosításáról 2020. július elsején lépett hatályba. A módosító javaslat benyújtásához készített általános indokolás szerint „célja a fiatalkorú személyek megóvása a szexuális kizsákmányolással szemben".

A statisztikai adatgyüjtés, valamint a jogalkalmazói, minősítési gyakorlat megváltozása mind hozzájárult ahhoz, hogy 2020-ban a regisztrált büncselekmények száma emberkereskedelem tekintetében jelentősen nőtt ${ }^{3}$, és a rendelkezésre álló 2021-re vonatkozó adatok is további emelkedést jeleznek.

A büncselekmények száma mellett a bünelkövetők száma is emelkedett, és a korábban már tapasztalt magas női elkövetői arány jelentősnek mondható. Ez a tendencia a nemzetközi adatokban is már látható, bár némileg alacsonyabb, az emberkereskedelem büntettével vádoltak 35\%-a volt nő 2016-ban (United Nations Office On Drugs And Crime, 2018 és Lightowlers, Broad \& Gadd, 2021). A női elkövetők emberkereskedelemben betöltött szerepével kapcsolatban további hazai kutatások szükségesek.

3 2018-ban négy, 2020-ban 57 regisztrált emberkereskedelem büncselekményt mutat az ENYÜBS. 
Az emberkereskedelem és a kényszermunka-büncselekmények sértettjei jellemzően a rászoruló, érzelmi és anyagi depriváltságban élők, esetleg fogyatékos emberek (nemtöl függetlenül), akik különösen ki vannak téve a mielőbbi gyors (nemcsak anyagi) haszonért (előnyért) bármilyen eszközt alkalmazó elkövetőknek.

\section{Pandémia és a magyar bünözés alakulása}

A bünözés és a társadalmi folyamatok összefüggése szinte a kriminológia kezdete óta az egyik fő kutatási terület. A büncselekmények számát három dolog befolyásolja: a makrogazdasági tényezők, a demográfiai változások/jellemzők és a technológiai újdonságok, ezeknek az emberkereskedelem jelenség esetében is kiemelt jelentöségük van (Kerezsi \& Pap, 2017).

Ebből a szempontból a COVID-19-járvány sok tanulsággal szolgál: a világjárvány mindenre kihatott, annak társadalmi, gazdasági, makro- és mikorszintü, egészségügyi - és sorolhatnánk - hatásaival a kutatók szinte azonnal elkezdtek foglalkozni.

Korábbi tapasztalatok tanulságul szolgálhatnak. A 2008-as világválság és a bűnözés alakulása közötti kapcsolatról az UNODC jelentése alapján elmondható, hogy bizonyíthatóan növelte a bünözés volumenét, a gazdasági tényezők kimutatható hatással vannak a bünözés alakulására. Az UNODC által készített modell időbeli eltolódást mutat a gazdasági mutatók és a statisztikai adatok változása között, amely 4-6 hónap átlagosan (United Nations Office On Drugs And Crime, 2010; Gál, 2020). A pandémiával kapcsolatban ugyanakkor egy különös kettősség állt fenn: egyrészt a lezárások, a karantén miatt a négy fal között megvalósított büncselekmények száma szinte azonnali emelkedést mutatott az első hullámban, másrészt egyes büncselekmények emelkedése valóban ezen átfutási időt követően növekedett. 2020 tavaszán Gál István László azt vetítette előre, hogy a személy elleni büncselekmények száma növekedni fog, valamint, hogy a közrend elleni büncselekmények először csökkenő (karantén intézkedések miatt), majd növekvő tendenciát mutatnak (a kijárási korlátozások megszünése miatt) (Gál, 2020).

Emiatt természetesen 2020 végén látható volt, hogy a bünözésre is hatással volt és lesz is a világjárvány. Véleményem szerint rövid- és hosszútávú hatásai is vannak, különösen amiatt, hogy a különböző hullámok másként hatottak. Az emberkereskedelem számaiban mutatkozó növekedés (Sólyomfi, 2021) ugyanakkor még nem a világjárvány következménye, sokkal inkább az azt megelőző évek munkájának eredménye. 
Az első hullám során ,új jelenségek mutatkoztak a bünözés területén is globálisan és Magyarországon egyaránt. Bár Magyarországon, a nyugat-európai országokkal ellentétben nem voltak eröszakos tiltakozó mozgalmak, és az eröszakos cselekmények összes száma a járvány idején csökkenni látszott, a gyülölet új, a büncselekményi szintet el nem érö, de mindenképpen fenyegetö formái jelentek meg" (Póczik, Sárik, Vass \& Bolyky, 2021).

Az első hullámot követően szinte azonnal megjelentek azok a jelzések, hogy a tavaszi karantén ideje alatt milyen jelentős mértékben nőtt a családon belüli erőszak jelenléte, például az Országos Kríziskezelő és Információs Telefonszolgálathoz (OKIT) érkező hívások számának emelkedése is erre utal. A pandémiát megelőző évek hasonló időszakához képest 16\%-kal többen hívták az OKITot (URL2), az első hullámot követően azonban, a második és harmadik során bevezetett korlátozó intézkedések idején, ez már nem volt ennyire jellemző.

A világjárványból fakadó bizonytalanságérzetet a munkahelyek elvesztése, illetve annak lehetősége felerősítette, amelyet a bezártság és az otthoni alkoholfogyasztás gyakoribbá válása tovább rontott. Ezek azonban mind hozzájárultak ahhoz, hogy a közvetlen családtagok váljanak elkövetővé és áldozattá (Póczik et al., 2021). Ez a tendencia nemcsak hazánkban jelent meg, a nemzetközi tapasztalatok ugyanezt a jelenséget tárták fel (URL3).

\section{A világjárvány hatása az emberkereskedelemre}

A családon belüli erőszak és az emberkereskedelem kapcsolódási pontjáról, hasonlóságáról és különbségeiről éppen a Belügyi Szemlében már volt szó (Windt, 2020a). Sok esetben az a tapasztalat, hogy a sértett bántalmazottként kapcsolati erőszak miatt került a hatóságok látókörébe, és ezt követően kis idő elteltével derült fény arra, hogy szexuális kizsákmányolás áldozata is. Emiatt nyilvánvaló, hogy ha az egyikben emelkedés mutatkozik (márpedig a családon belüli erőszak rendkívüli módon felerősödött az első hullámban), akkor a másikban (értsd: emberkereskedelem) is előbb-utóbb a pandémia hatása szintén érzékelhető lesz. Különösen amiatt is, mivel az emberkereskedelem jelensége jellemzően a gazdaságilag nehéz helyzetben lévők körében a legelterjedtebb, és mint láthattuk a pandémia egyik szinte azonnali következménye egy komoly gazdasági visszaesés volt.

A 2021 nyarán megjelent úgynevezett TIP jelentés (az Amerikai Egyesült Államok Külügyminisztériuma által évente kiadott emberkereskedelem elleni jelentés) már szól a világjárvány emberkereskedelemre tett hatásáról. A TIP jelentés készítői a világ 180 országában tapasztaltak alapján azt fogalmazták meg, hogy 
a pandémia világszerte tovább fokozta az emberkereskedelmi tevékenységet. „A járvány negativ gazdasági és társadalmi hatásai miatt a hátrányosan érintett rétegekböl még többen kerültek kiszolgáltatott helyzetbe az emberkereskedökkel szemben, elsősorban a szexuális kizsákmányolás és a kényszermunka vonatkozásában. Szintén a járványnak tudható be, hogy a fokozott internethasználat következtében az emberkereskedők egyre inkább a virtuális teret használják az áldozataik kiválasztására, föként a kiskorúak körében. A pandémia - lefoglalva a kormányok eröforrásait - is hozzájárult ahhoz, hogy a 2020-as évben számottevően visszaesett a megelözésre és az áldozatok támogatására irányuló figyelem, amit az emberkereskedök jelentös mértékben kihasználtak." (Department of State, 2021; Asongu \& Usman, 2020; Diop, Asongu \& Nnanna, 2021). A mindennapjainkban jelentős szerepet betöltő digitális világ a pandémia hatására még elterjedtebbé vált. 2020 márciusától - az első karantén kihirdetését követően - az oktatás is a digitális térbe helyeződött át, amely 2020 novemberétől a középiskolákat érintően tovább is folytatódott. Az életünk még több területe a társadalmi távolságtartás miatt is az online felületeken zajlott, így nem meglepően az emberkereskedelem folyamatának egyes részei is: a toborzás során, valamint a hirdetések elérhetővé tételekor (Latonero, 2011; Milivojevic, Moore \& Segrave, 2020).

A gyermekek (18 év alattiak) szexuális kizsákmányolásának elszaporodása különösen figyelemfelkeltő tendencia ${ }^{4}$, bár korántsem új jelenség, annak kibertérben történő térnyerése az utóbbi évek digitális devianciáinak jelentős részét teszi ki, amely a COVID-19-járvány első hulláma idején még inkább megerősödött (Windt, 2020b).

A kutatók számára a 2020 tavaszi időszak lehetőséget biztosított vizsgálni az emberek viselkedését, az elszigeteltség, a kapcsolatok alakulásának helyzetét. A bezártság, a távoktatás, az internetalapú világ következményei és veszélyei, a bizonytalanságérzet és a betegségtől való félelem az első hullám után, s az ezt követőkben további kérdéseket vetett fel (Pléh, 2021).

A korábbi vizsgálataink során a VIII. kerület gócpontként körvonalazható a szexuális kizsákmányolás tekintetében. Emiatt is izgalmas, hogy az első hullámban a kutatók igyekeztek feltárni a járvány helyi hatásait. Ez alapján Budapest VIII. kerületében a fiatal felnőtteket sokkal jobban érintette a járvány hatása egzisztenciális szempontból, mint az idősebbeket. Az iskolázottság vonatkozásában leginkább a szakmunkás végzettségüek, legkevésbé a diplomások érintettek. A jövedelmi helyzet tekintetében pedig a legszegényebbek körében

4 Különbséget kell tenni a gyermekek szexuális bántalmazása, kizsákmányolása és a gyermekkereskedelem között (Council of Europe, 2016). 
mérték a legnagyobb arányt, 60\%-ot, akiket a leginkább érintett a koronavírus-járvány első hulláma. Az érintettek értelemszerüen sokkal rosszabbul élték meg a veszélyhelyzet időszakát azokhoz képest, akiket egzisztenciálisan nem érintett. Elöbbi csoportban 69\%, utóbbiban 32\% nyilatkozott úgy, hogy inkább rosszul élte meg. Mindez egyben azt is jelenti, hogy azok körében is vannak olyanok, akik jól élték meg a járványt, akiket egzisztenciálisan hátrányosan érintett (28\%). Másfelöl attól, hogy nem történt anyagi vagy munkaügyi hátrány, más tényezők még okozhatták azt, hogy a járványt nehezen élték meg: a nem érintettek 32\%-a érzi így. Az érintettek 46\%-a tapasztalt magán valamilyen lelki problémát. Ez magasabb, mint a másik csoportban mért 31\%-os érték (Hunyadi \& Molnár, 2020; Szirmai, 2021; Pál et al., 2021).

A pandémia első hulláma során körvonalazódtak a vírus terjedése szempontjából a leginkább sérülékeny csoportok: az idősek, a hátrányos helyzetü, eleve rossz szociális helyzetben lévők, a mentális betegségekkel küzdők még kiszolgáltatottabbá váltak. A szexuális kizsákmányolás során az áldozatok jelentős része kiskorú, mentális zavarban szenved, míg a munkacélú kizsákmányolás során jellemzően az idősebb korosztály tagjai érintettek, akik jellemzően alkoholproblémákkal küzdenek, és sok esetben munkanélküliek. Az érintetti körök hasonlósága miatt szintén egyértelmünek látszik az, hogy az emberkereskedelemre is jelentős mértékben befolyással volt a világjárvány, sőt, mint ahogy láttuk korábban, még többen váltak anyagilag is kiszolgáltatott helyzetbe.

Említettük, hogy a negyedik hullámban már jól látható, hogy különbség mutatkozik az egyes hullámok között, amelyek különböző módon hatottak a szexuális- és a munkacélú kizsákmányolásra is.

A szexuális kizsákmányolás prostitúcióval összefüggő tevékenységeire jelentösen hatott a pandémia. Az első hullám elején (2020 tavasza), amikor még kevés ismeretünk volt a vírus természetéről, még kevéssé volt érezhető az a visszaesés, amely 2020 közepére, de különösen decemberére már egyértelmüvé vált. A prostituáltak továbbra is vállalták a munkát, ugyanakkor a kliensek - a bevételkiesés és a kijárási korlátozások következtében - elmaradoztak. Az utcai prostitúció visszaszorulása már a világjárvány előtt is elkezdődött, ez azonban tovább erősítette azt, hogy a hirdetési felületek az online térbe helyeződtek át, illetve munkásszállókban, motelekben, magánlakásokban nyújtották a szexuális szolgáltatásokat.

A testi érintkezés szükségszerüsége okán a fertőzésveszély megsokszorozódott, a nemi betegségektől való félelem mellett a koronavírustól való aggódás is jelentkezett a prostitúciós tevékenység végzése során. A német és a holland hatóságok 2020. márciusban - a koronavírus-járvány terjedésének megfékezése érdekében - betiltották a szexuális szolgáltatások nyújtásának lehetőségét 
a bordélyházakban, hiszen Németországban és Hollandiában ez legális volt korábban. Ezt követően a prostituáltak egy része illegálisan folytatta a tevékenységét, már nem bordélyházban, hanem motelekben, sokkal rendezetlenebb körülmények között, még kiszolgáltatottabban. Németországban 2019 végén 40 400 (ebből 1800 magyar állampolgár), 2020 végére 38\%-kal kevesebben, csupán 24940 regisztrált prostituált volt (URL4). Mindkét említett ország egyes tartományaiban 2020 nyarán feloldották a szexuális szolgáltatások nyújtásának tilalmát, de ez nem volt egységes gyakorlat.

Az emberkereskedelem esetében hazánkban sokáig a határon átnyúló jelleget emeltük ki, holott 2019-ben is már látható volt, hogy ez némileg változott, és a szexuális kizsákmányolás esetében a hazai megvalósítás is jelentős volt, az esetek közel felében. A pandémia egyik jelentős hatása, hogy a határon átnyúló jelleg az egyes hullámokra reagált a határok lezárása függvényében. A világjárványt megelőzően a külföldön foglalkoztatott prostituáltakat 2-3 hét után hazahozták ,pihenni”, illetve a foglalkoztatási helyüket gyakran változtatták. Az első hullámban még erre nemigen tudtak az elkövetők felkészülni, de a második, harmadik hullámban, amikor már látható volt, hogy újabb szigorításokat vezetnek be, amely a határokra is vonatkozik majd, igyekeztek mielőbb külföldre vinni a prostituáltakat, akiknek hosszabb ideig kellett kint tartózkodniuk. Azaz az elkövetők igen gyorsan alkalmazkodtak az új helyzetekhez az első hullámot követöen.

Emellett számos külföldön dolgozó prostituált hazajött, mert már nem tudott nyugodt körülmények között dolgozni, és a bevételei jelentősen megcsappantak. Ahogy az egyik áldozat fogalmazott, hogy 2020 végén miért jött haza Németországból: „Na már másodszor, amikor a kommandósok és a rendörök is ránk törték az ajtót és bilincsbe vittek el, akkor azt mondtam, hogy pffuuu ... hát ... hát ezt nem."

A kijárási korlátozások, a határzárások miatt a helyi viszonylat erősödött: a nemzetközi tapasztalatok alapján az elkövetők a saját környezetükből toboroztak, és sokkal inkább ott is valósították meg a büncselekményeket (United Nations Office On Drugs And Crime, 2021).

A prostitúciós tevékenység folytatásához az érintettek jelentős részének szüksége van valamilyen tudatmódosító szerre: alkoholra és/vagy drogra, de az emberkereskedők is alkalmazzák ezeket, hiszen a sértett felett gyakorolt irányítás megszerzésének egyik hatékony eszköze a sértett addikciójának kialakítása, vagy a már meglévő függőség kihasználása. A sértett drog- vagy alkoholfüggőségének a munka elvégzése során jelentősége van, sokkal inkább hajlandó bármit megtenni. A függőség kialakítása az áldozat szempontjából is segítség, hogy az elvégzendő tevékenység könnyebben menjen. 
Ugyanakkor az emberkereskedelemböl való kilépés során ez egy rendkívül nagy nehézség: a függőség kezelése, a megfelelő orvos megtalálása időigényes. Az alkohol könnyedén elérhető maradt a világjárvány miatt bevezetett lezárások alatt is, ugyanakkor a kábítószer-fogyasztók nehéz helyzetbe kerültek. Hiszen ők ,a szigorú korlátozások idején nem, vagy csak nehezen juthatnak szakszerü segitséghez, és akik a drogpiac változása miatt jóval drágábban kénytelenek beszerezni az adagjukat. Emiatt egyre többen választják az intravénás alkalmazást vagy térnek át más, olcsóbb, hozzáférhetöbb szerekre. Ez pedig nemcsak az egészségügyi kockázatot növeli meg, de a szerhatás alatt történö bünelkövetések gyakoriságának emelkedésével is számolni kell" (Ritter, 2020).

A munkacélú kizsákmányolásról jelen tematikus szám egy másik tanulmányában (Balogh \& Windt, 2021) bővebben szó esik, itt csak annyira térnénk ki, hogy a koronavírus-járvány miatt sokan elvesztették az állásukat, volt néhány szektor, például az építőipar, ahol munkaerőhiány is jelentkezett, amelyet magyar szakemberekkel nem lehetett pótolni, így harmadik állam polgárainak a segítségét kellett kérni. Számos visszaélés történt a sérelmükre, néhányukat emberkereskedelem áldozataként azonosították 2021-ben, amire korábban alig volt példa.

\section{Zárógondolatok}

Az első hullám sokkhatását követően elmondható, hogy az Magyarországon enyhe lefolyású volt, emiatt a 2020 öszi második hullámban már sokkal kevésbé vettük komolyan a korlátozó intézkedéseket, azonban 2020 novemberétől már kijárási korlátozás volt. 2021 tavaszán, a harmadik hullám volt az eddigiek közül a legsúlyosabb, a legtöbb áldozatot követelő. Ekkorra - már jobban ismerve a vírust - sokkal tapasztaltabban éltük meg a zárást, sőt az oltóanyagok némi reményt is adtak a tekintetben, hogy a világjárvány leküzdhető rövid időn belül. Ennek óriási jelentősége lenne, hiszen a negyedik hullámban már a súlyosabb mentálhigiénés problémák járványszerủ elterjedésének, a „pszichodémiának" a megelőzése is fontossá válik (Osváth, 2021).

Rövid távon egyértelmủen látható a pandémia emberkereskedelemre tett hatása: a családon belüli erőszak nőtt, a módszerek változtak, ugyanakkor elindult egy átstruktúrálódás, amelynek hosszú távú következményei még nem ismertek. Annyi bizonyos, hogy az egyébként is jelentős látenciában lévő jelenség még kevésbé volt szem előtt, amely a segítők munkája mellett az ellene fellépőkét is megnehezítette (United Nations Office On Drugs And Crime, 2021).

A pandémia hatását a fogyatékkal élők tekintetében az ENSZ már nagyon korán megfogalmazta, szerintük a COVID-19 globális válsága elmélyíti a meglévő 
egyenlőtlenségeket, felfedi a kirekesztés mértékét, és kiemeli, hogy a fogyatékossággal élő emberek önrendelkező életének elősegítése, befogadásuk támogatása elengedhetetlen a járvány idején is (Sándor, Cserti-Szauer, Antal, Katona \& Kunt, 2020).

A fogyatékosok mellett a gyermekek váltak még kiszolgáltatottabbá: a szüleik munkahelyük elvesztése, a két alkalommal elrendelt karantén, az iskolák, óvodák zárása rendkívül komoly mentális terhet jelentett. Emellett az iskolák, óvodák zárása a jelzőrendszeri tagokat is kivette a rendszerből, nemigen tudtak kitől segítséget kérni (United Nations Office On Drugs And Crime, 2021). A gyerekotthonokban az első zárást követően ${ }^{5}$ a szökések számának emelkedésével kalkuláltak az ott dolgozók, ugyanakkor inkább az volt a tapasztalat, hogy nem volt nagyon lehetőség hova menni, emiatt inkább bent maradtak a gyerekek.

Ugyanakkor a gyermekek szexuális kizsákmányolása az online térre helyeződött át, illetve a prostitúció munkásszállókon, motelekben jelent meg. Egyes tapasztalatok szerint a 18 év alattiakról készített felvételeket zárt csoportokban kezdték terjeszteni, és csak ezen körből kerülhetnek ki a kliensek, akiknek a hirdetésben szereplő telefonszám felhívását követően mondták el a helyszín pontos címét (The effects of the COVID-19, 2021).

Az egyik legérzékletesebb következménye a világjárványnak a szexuális kizsákmányolás tekintetében a híres kölni Pascha bezárása volt 2020 őszén: itt 10 emeleten 120 prostituált üzte tevékenységét, napi 1000 kuncsaft legnagyobb örömére (URL5). A prostituáltaknak a zárások feloldását követően mindig volt egy kis lélegzetvételnyi ideje, amikor megpróbálták a tevékenységüket folytatni, de a nyugat-európai bordélyházak ideiglenes bezárása a prostitúciós szabályozások átgondolását is eredményezték. 2021. november 15-én a Pascha újra nyitotta kapuját, az alábbi szlogennel: „,Aki nem jön ide, megbánja” (URL6).

Megemlítendő még egy fontos dolog: a COVID-19-világjárvány hatalmas kihívások elé állította az emberkereskedelem elleni küzdelmet nemzetközi és nemzeti szinten is (United Nations Office On Drugs And Crime, 2021), ugyanakkor a hazai jogalkalmazók online képzése, a jelenség változásaira történő azonnali reagálás, a korábbi évek munkája segíthet ennek a nehézségnek a leküzdésében is.

A negyedik hullám felszálló ágában, 2021 végén készült ez a tanulmány. Egyelőre ennyi látható az elmúlt közel két év eseményeiből: az emberkereskedelem a bünügyi statisztikákban emelkedést mutat, átalakulás jellemzi, a negatív gazdasági hatások nem kerülték el ezt a jelenséget, ám további kutatások, interjúk szükségesek ahhoz, hogy a mélyebb összefüggéseket feltárjuk.

5 2020. március 16. 


\section{Felhasznált irodalom}

Asongu, S. A. \& Usman M. U. (2020). The COVID-19 pandemic: Theoretical and practical perspectives on children, women and sex trafficking. Health Care for Women International, 41(11-12), 1384-1397. https://doi.org/10.1080/07399332.2020.1849219

Balogh K. \& Windt Sz. (2021). A munkáltatással összefüggésben elkövetett emberkereskedelem jellemzői elméleti és gyakorlati szempontból. Belügyi Szemle, 70(2), 261-277. https:// doi.org/10.38146/BSZ.2022.2.3

Council of Europe (2016). Trafficking in Children. Thematic Chapter of the 6th General Report on GRETA's Activities. https://rm.coe.int/6gr-extract-web-en/16808b6552

Department of State (2021). TIP Report 2021. Department of State, United State of America. https://www.state.gov/wp-content/uploads/2021/09/TIPR-GPA-upload-07222021.pdf

Diop, S., Asongu, S. A. \& Nnanna, J. (2021). COVID-19 economic vulnerability and resilience indexes: Global evidence. International Social Science Journal, 18, 107243. https://doi. org/10.1111/issj.12276

European Comission (2020). Study on the economic, social and human costs of trafficking in human beings within the EU. European Comission. https:/ec.europa.eu/anti-trafficking/system/files/2020-10/study_on_the_economic_social_and_human_costs_of_trafficking_in_human_beings_within_the_eu.pdf

Gál I. L. (2020). A koronavírus (COVID-19) és az általa okozott gazdasági világválság lehetséges hatásai a bünözésre. Magyar Jog, 67(5), 257-265.

Hatvani E., Sebhelyi V. \& Vaskuti G. (2018). Gyermekprostitúció visszaszoritása, gyermekkereskedelem. Szociális és Gyermekvédelmi Főigazgatóság. https://docplayer.hu/164169682-Szocialis-es-gyermekvedelmi-foigazgatosag-gyermekprostitucio-visszaszoritasa-gyermekkereskedelem.html

Holka L. (2021). ILO Szemle: A COVID19 és a munka világa. Nemzetközi Statisztikai Figyelö, 7(1), 23-26.

Hunyadi B. \& Molnár Cs. (2020). A koronavírus-járvány gazdasági és társadalmi következményei Józsefvárosban. Friedrich-Ebert-Stiftung - Political Capital. http://library.fes.de/pdf-files/ bueros/budapest/16522.pdf

Huszár J. \& Windt Sz. (2020). Szemléletformáló tréning, avagy a rendőr, az ügyész, a bíró és öt emberkereskedelmes ügy. Ügyészek Lapja, 27(1), 57-65.

International Labour Organization (2020). ILO Monitor: COVID-19 and the world of work. 2nd edition. ILO.

Kerezsi K. \& Pap A. L. (2017). A bűnözés és a bünözéskontroll jövője. In Finszter G. \& Sabjanics I. (Szerk.), Biztonsági kihívások a 21. században (pp. 542-584). Dialóg Campus.

Latonero, M. (2011). Human Trafficking Online: The Role of Social Networking Sites and Online Classifieds. University of Southern California. https://doi.org/10.2139/ssrn.2045851 
Lightowlers, C., Broad, R. \& Gadd, D. (2021). Victims and suspects of modern slavery: Identifying subgroups using latent class analysis. Policing: A Journal of Policy and Practice, 15(2), 1384-1398. https://doi.org/10.1093/police/paaa072

Milivojevic, S., Moore, H. \& Segrave, M. (2020). Freeing the Modern Slaves, One Click at a Time: Theorising human trafficking, modern slavery, and technology. Anti-Trafficking Review, (14), 16-32. https://doi.org/10.14197/atr.201220142

Osváth P. (2021). A COVID-19-pandémia mentálhigiénés következményei. Hogyan tudunk felkészülni a pszichodémiás krízisre? Orvosi Hetilap, 162(10), 366-374. https://doi. org/10.1556/650.2021.31141

Pál V., Uzzoli A., Boros L., Fabula Sz., Trócsányi A., Nagy G., Pirisi G. \& Kovalcsik T. (2021). Életkörülmények, életminőség. In Kocsis K. (Főszerk.), Magyarország Nemzeti Atlasza- Társadalom (pp. 150-159.). Csillagászati és Földtudományi Kutatóközpont, Földrajztudományi Intézet.

Pléh Cs. (2021). Az embert körülvevő kapcsolati háló és a járvány próbatevése. Magyar Tudomány, 182(10), 1317-1334.

Póczik Sz., Sárik E., Vass P. \& Bolyky O. (2021). A COVID-19 pandémia egyes kriminológiai aspektusai, Belügyi Szemle, 69(3), 375-396. https://doi.org/10.38146/BSZ.2021.3.2

Ritter I. (2020). Karanténban a drogpiac? A COVID 19 pandémia hatásai a globális drogpiacra. Ügyészek lapja, 27(4-5), 35-49.

Sándor A., Cserti-Szauer Cs., Antal Zs., Katona V. \& Kunt Zs. (2020). Pillanatgondolatok a COVID-19 járványról. Fogyatékosság és Társadalom, 6(1), 5-9. https://doi.org/10.31287/ FT.hu.2020.1.1

Sólyomfi A. H. (2021). A Magyarországon regisztrált bűncselekmények változásának alakulása a Covid-19 járvány időszakában, Studia Mundi-Economica, 8(3), 86-96. http://studia.mundi. gtk.szie.hu/sites/default/files/upload/studia/2021-vol8-no3/studia_mundi_vol_8_no_3_c7.pdf Somogyi G. (2020). Az emberkereskedelem értelmezésével kapcsolatos bírói gyakorlat, Forum Sententiarum Curiae, (1), 10-11. https://kuria-birosag.hu/sites/default/files/fsc_tanulmany/ drsomogyi.pdf

Szirmai V. (2021). Nagyvárosok a Covid-19 vírusjárvány idején. Földrajzi Közlemények, 145(1), 1-16. https://doi.org/10.32643/f k.145.1.1

Tóth I. Gy. \& Hudácskó Sz. (2020). A koronavírus-járvány társadalmi hatásai a közvélemény-kutatások tükrében. In Kolosi T., Szelényi I. \& Tóth I. Gy. (Szerk.), Társadalmi Riport 2020. (pp. 553-572). TÁRKI Társadalomkutatási Intézet Zrt.

United Nations Office On Drugs And Crime (2010). Monitoring The Impact Of Economic Crisis On Crime. UNODC. https://www.unodc.org/documents/data-and-analysis/statistics/crime/ GIVAS_Final_Report.pdf

United Nations Office On Drugs And Crime (2018). Global Report on Trafficking in Persons. UNODC. https://www.unodc.org/documents/data-and-analysis/glotip/2018/GLOTiP_2018_ BOOK_web_small.pdf 
United Nations Office On Drugs And Crime (2021). The effects of the COVID-19 pandemic on trafficking in persons and responses to the challenges, UNODC. https://www.unodc.org/ documents/human-trafficking/2021/The_effects_of_the_COVID-19_pandemic_on_trafficking_in_persons.pdf

Windt Sz. (2014). 2013, az emberkereskedelem elleni fellépés éve Magyarországon. Belügyi Szemle, 62(1), 67-74.

Windt Sz. (2020a). Az emberkereskedelem és a családon belüli erőszak- hasonlóságok és különbségek. Belügyi Szemle, 68(6), 105-117. https://doi.org/10.38146/BSZ.2020.12.5

Windt Sz. (2020b). A gyermekek szexuális kizsákmányolásáról. Ügyészségi Szemle, 5(4), 42-53. http://ugyeszsegiszemle.hu/hu/202004/ujsag\#42

Windt Sz. (2021a). A láthatatlan emberek. Az emberkereskedelem jelensége Magyarországon. Országos Kriminológiai Intézet.

Windt Sz. (2021b). „Aki még nincs 18 éves, az tabu” - egy gyermekprostitúcióról tartott kerekasztal-beszélgetés összegzése. Ügyészek Lapja, 28(5), 49-55.

\section{A cikkben található online hivatkozások}

URL1: Tudomány a COVID okozta társadalmi sokk kezelésének jelen fázisában. https://mta. hu/mta_hirei/tudomany-a-covid-okozta-tarsadalmi-sokk-kezelesenek-jelen-fazisaban-110837

URL2: Családi tüzfészkekböl menti az áldozatok életét az állam. https://index.hu/gazdasag/2021/05/26/okit-telefonszam-bantalmazas-csaladon-beluli-eroszak-emberkereskedelem/

URL3: The Covid-19 pandemic and intimate partner violence against women in the EU, 2021. https://eige.europa.eu/publications/covid-19-pandemic-and-intimate-partner-violence-against-women-eu

URL4: Registered sex workers in Germany drop sharply in pandemic. https://apnews.com/article/ europe-germany-coronavirus-pandemic-pandemics-health-43dec $11288056622589 \mathrm{fec} 60 \mathrm{fa} 64 \mathrm{e} 780$

URL5: Bezár a bazár: Európa egyik legnagyobb bordélyát is csödbe vitte a vírus. https://privatbankar.hu/cikkek/makro/bezar-a-bazar-europa-egyik-legnagyobb-bordelyat-is-csodbevitte-a-virus.html

URL6: Safety first. https://www.pascha.de

\section{Alkalmazott jogszabályok}

A Kormány 1046/2020. (II. 18.) Korm. határozata az emberkereskedelem elleni küzdelemről szóló 2020-2023 közötti nemzeti stratégiáról, valamint annak végrehajtását szolgáló, 20202021 közötti időszakban végrehajtandó intézkedési tervröl 
2020. évi V. törvény az emberkereskedelem áldozatainak kizsákmányolása elleni fellépés érdekében szükséges egyes törvények módosításáról

\section{A cikk APA szabály szerinti hivatkozása}

Windt Sz. (2022). A világjárvány hatása az emberkereskedelemre az első két év tapasztalatai alapján. Belügyi Szemle, 70(2), 327-344. https://doi.org/10.38146/BSZ.2022.2.6 